\title{
IMPLEMENTASI CSR MELALUI PROGRAM “KAMPOENG BNI" OLEH PT. BNI (PERSERO) TBK
}

\author{
Mayang Riyantie \\ Universitas Subang
}

\begin{abstract}
ABSTRAK
Penelitian ini menunjukan bahwa latar belakang dilaksanakannya Program "Kampoeng BNI" karena perwujudan misi, kewajiban perusahaan kepada Undang-Undang, sebagai tanggung jawab sosial perusahaan (CSR), dan membantu ekonomi masyarakat Indonesia. Implementasi Program "Kampoeng BNI" dilakukan melalui dua tahap, tahap pertama SKC Melawai dan tahap kedua Divisi CCR melaksanakannya dengan tahap penyaluran dana, Pembentukan Program, dan Peresmian. Faktor penentu kemenangan BNI untuk kategori CSR yaitu, kerangka CSR, ikuti panduan dan standar internasional tentang CSR, komunikasikan komitmen CSR, implementasi dan pengukuran program CSR.
\end{abstract}

Kata-kata kunci: Implementasi CSR, BNI, dan ASEAN BAC

\section{CSR IMPLEMENTATION THROUGH THE “KAMPOENG BNI” PROGRAM BY PT. BNI (PERSERO) TBK}

\begin{abstract}
The research results shows that the background of "Kampoeng BNI" program implementation is triggered by the company's mission and the company's obligations to the Law, to have Corporate Social Responsibility (CSR), and to help the economy of Indonesian people. The "Kampoeng BNI" program has been done by two processes, the first process is through SKC Melawai. The second process is through CCR (Corporate Community Responsibility) division with three stages: funds distribution, program formation, and the inauguration. The factor that makes BNI winning the CSR category because BNI met the criteria for ASEAN BAC. The categories include, CSR Frameworks, Following International guidelines and standards on CSR, Communicating the Commitment to CSR, Implementation and measurement of CSR Program.
\end{abstract}

Keywords: Implementation of CSR , PT. BNI (persero) tbk., and ASEAN BAC

Korespondensi: Mayang Riyantie, S.I.Kom., M.I.Kom. Universitas Subang, Jl. RA Kartini KM 3 Subang. Email: namanya.mayang@gmail.com 


\section{PENDAHULUAN}

PT. Bank Negara Indonesia (persero) tbk (selanjutnya ditulis dengan $\mathrm{BNI}$ ) beberapa tahun terakhir sedang giat melakukan pengembangan ekonomi masyarakat melalui program "Kampoeng BNI". "Kampoeng BNI pertama kali dibentuk pada tahun 2007. Program "Kampoeng BNI" mengusung konsep klasterisasi usaha-usaha kecil sejenis yang terpusat di satu lokasi yang sama.

Tujuan pembentukan "Kampoeng BNI" adalah "untuk mengembangkan potensi ekonomi masyarakat di suatu kawasan pedesaan melalui pinjaman lunak program kemitraan maupun bantuan dalam rangka capacity building bagi masyarakat di daerah tersebut" (BNI, 2012). Program pemberdayaan tersebut diharapkan akan berdampak luas terhadap peningkatan derajat hidup masyarakat di sekitar "Kampoeng BNI".

Pemberdayaan ekonomi yang diberikan adalah dalam bentuk pinjaman berbunga sangat ringan, yakni 6 persen per tahun, kepada pelaku usaha di dalam Kampoeng BNI dengan kisaran batas kredit Rp 2 juta - Rp 10 juta. Pinjaman yang diberi nama Kredit Program Kemitraan ini bersifat dana bergulir, sehingga setiap pelaku usaha di Kampoeng BNI dapat menerima manfaatnya secara bergantian. Fasilitas kredit tersebut tidak dapat dinikmati oleh sembarangan orang, hanya pelaku usaha pemula yang berkeinginan mengembangkan usahanya namun tidak memiliki modal yang cukup. Syarat pelaku usaha salah satunya tidak memiliki agunan kredit, namun tengah membangun bisnis yang potensial.

Program Kampoeng BNI yang diteliti oleh peneliti berlokasi di Kampoeng BNI" Muara Angke. Mitra binaan BNI Muara Angke berjumlah 16 orang. BNI dengan memberikan pinjaman modal kepada mitra binaan atau pelaku usaha di "Kampoeng BNI" yang sudah berkembang dengan Kredit Program Kemitraan diharapkan akan melakukan ekspansi bisnisnya dengan dukungan Kredit Usaha Rakyat (KUR), skema kredit yang dapat memberikan plafon pinjaman hingga Rp 20 juta namun dengan suku bunga sekitar 13 persen, dan jika mereka berhasil dengan pengembangan usahanya, mereka kemudian layak untuk mendapatkan dukungan kredit komersial BNI dan pada akhirnya menja- di nasabah loyal BNI. BNI memiliki cara yang berbeda dalam mendistribusikan pendanaan tanggung jawab sosialnya yakni dengan mengalokasikan 4 persen dari seluruh anggaran perusahaan untuk mendanai pelatihan sumber daya manusia, sesuai dengan aturan Bank Indonesia (BI).

BNI berdiri sejak 1946. BNI yang dahulu dikenal sebagai Bank Negara Indonesia, merupakan bank pertama yang didirikan dan dimiliki oleh Pemerintah Indonesia. Bank Negara Indonesia mulai mengedarkan alat pembayaran resmi pertama yang dikeluarkan Pemerintah Indonesia, yakni ORI atau Oeang Republik Indonesia, pada malam menjelang tanggal 30 Oktober 1946, hanya beberapa bulan sejak pembentukannya. Bank Negara Indonesia lalu ditetapkan sebagai bank pembangunan, dan kemudian diberikan hak untuk bertindak sebagai bank devisa, dengan akses langsung untuk transaksi luar negeri. Di Indonesia sendiri, BNI sedang berupaya mengembangkan kehidupan masyarakat, hal ini sejalan dengan salah satu misi BNI yakni "Meningkatkan kepedulian dan tanggung jawab terhadap lingkungan dan sosial" (BNI, 2012).

Idealnya perusahaan yang baik tidak hanya memburu keuntungan semata melainkan memiliki kepedulian pada kelestarian lingkungan dan kesejahteraan masyarakat. Saat ini tidak sedikit perusahaan yang semakin merasakan pentingnya berbagi dan memiliki kepedulian, meskipun awalnya kepedulian merupakan sebuah ke-terpaksaan, namun kini tidak sedikit yang menyadari ada sejumlah nilai positif yang akan kembali ke perusahaan bila mampu berbagi kepedulian terhadap masyarakat. Seiring dengan perkembangan kesadaran perusahaan akan pentingnya hubungan dengan masyarakat maka berkembang pula konsep Corporate $S_{0}$ cial Responsibility (selanjutnya ditulis dengan CSR). CSR merupakan "Suatu tindakan atau konsep yang dilakukan oleh perusahaan (sesuai kemampuan perusahaan tersebut) sebagai bentuk tanggung jawab mereka terhadap sosial atau lingkungan sekitar perusahaan berada" (Rachman dkk, 2011: 16).

Di Indonesia istilah CSR untuk BUMN disebut juga sebagai Program Kemitraan dan Bina Lingkungan (selanjutnya ditulis dengan PKBL). Dasar hukum PKBL adalah "Peraturan Menteri BUMN No.4 Tahun 2007, bahwa seti- 
ap BUMN wajib membentuk unit kerja khusus yang menangani langsung masalah pembinaan dan pemberdayaan masyarakat" (Kartini, 2009: 78). Berdasarkan hasil kutipan wawancara dengan Manager Program Kemitraan (PK), Muhammad Udaya mengaku bahwa "BNI sendiri menerapkan PKBL dan membaginya menjadi dua, antara lain Program Kemitraan (PK) dan Bina Lingkungan (BL). Program Kemitraan BNI berupa "Kampoeng BNI" sedangkan Bina Lingkungan terbagi lagi menjadi berupa bantuan bencana alam, pendidikan, kesehatan, sarana umum, sarana ibadah, dan lingkungan"". Keseriusan BNI dalam mengembangkan CSR melalui program Kampoeng BNI diberbagai wilayah Indonesia pada akhirnya membuahkan hasil. Itu terbukti dari kemenangan BNI dalam memperoleh penghargaan CSR terbaik se Asia Tenggara pada tanggal 17 November 2012 di Phnom penh Kamboja oleh The ASEAN Business Advisory Council (ASEAN-BAC) dengan Most Admired Enterprise in the Corporate Social Responsibility Category.

ASEAN Business Advisory Council (ASE$A N-B A C$ ) (selanjutnya ditulis ASEAN BAC) merupakan lembaga yang mendapat mandat untuk memberi masukan tentang keadaan dunia usaha. ASEAN-BAC setiap tahunnya dipercaya untuk membuat salah satu Event yang diberi nama dengan The ASEAN Business Award (ABA). ABA sendiri awal mulanya dibentuk pada tahun 2007 yang bertempat di Singapura. Dalam penghargaan tersebut, ABA membuat empat penghargaan yang berkategori diantaranya, "Growth (Pertumbuhan), Employment (Lapangan Kerja), Innovation (Inovasi) dan Corporate Social Responsibility (Tanggung Jawab Sosial Perusahaan)" (ASEAN-BAC, 2012).

Berdasarkan permasalahan yang telah diuraikan tersebut dijadikan landasan bagi peneliti untuk mengetahui implementasi CSR melalui program "kampoeng BNI" oleh PT BNI (persero) tbk sebagai program yang mendapatkan penghargaan CSR terbaik se Asia Tenggara melalui penghargaan Most Admired Enterprise in the Corporate Social Responsibility Category oleh The ASEAN Business Advisory Council (ASE-

1 Wawancara pra survei dengan Muhammad Udaya yang bertempat di Ged. BNI Sudirman Lantai 31 pada jam 13.40 Wib tanggal 21 Maret 2013
$A N-B A C)$.

Pertanyaan penelitian dalam penelitian ini yaitu bagaimana latar belakang dilaksanakannya Program "Kampoeng BNI" yang dilakukan oleh BNI?, bagaimana implementasi CSR melalui Program "Kampoeng BNI" hingga mendapatkan penghargaan CSR terbaik seAsia Tenggara?, dan bagaimana faktor-faktor penentu kemenangan BNI untuk kategori CSR terbaik se-ASEAN oleh ASEAN-BAC melalui program “Kampoeng BNI”?

\section{METODE PENELITIAN}

Paradigma menurut Guba dan Lincoln (1994) mengajukan tipologi yang mencakup empat paradigma: positivisme, postpositivisme, kritikal dan konstuktivisme. Dikemukakan oleh Guba, bahwa setiap paradigma membawa implikasi metodologi masing-masing (dalam Hidayat, 1999: 2).

Menurut pemikiran Weber, paradigma konstruktivisme menilai perilaku manusia secara fundamental berbeda dengan perilaku alam, karena manusia bertindak sebagai agen yang mengkonstruksi dalam realitas sosial mereka, baik itu melalui pemberian makna atau pemahaman perilaku dikalangan mereka sendiri.

Metode yang digunakan dalam penelitian ini adalah studi kasus. Dalam tradisi penelitian kualitatif dikenal terminologi studi kasus (case study) sebagai sebuah jenis penelitian. Menurut Creswell (1998: 37-38), fokus studi kasus adalah spesifikasi kasus dalam suatu kejadian, baik itu yang mencakup individu, kelompok budaya ataupun suatu potret kehidupan.

Creswell mengemukakan beberapa karakteristik dari studi kasus, yaitu (1) Mengidentifikasi "kasus untuk suatu studi (2) Kasus tersebut merupakan sebuah "sistem yang terikat" oleh waktu dan tempat (3) Studi kasus menggunakan berbagai sumber informasi dalam pengumpulan datanya untuk memberikan gambaran secara terinci dan mendalam tentang respons dari suatu peristiwa dan (4) Menggunakan pendekatan studi kasus, peneliti akan "menghabiskan waktu" dalam menggambarkan konteks atau setting untuk suatu kasus (Creswell, 1998: 36-37)

Berdasarkan paparan di atas, dapat diungkapkan bahwa studi kasus adalah sebuah eksplorasi dari "suatu sistem terikat" atau "suatu kasus atau beragam kasus" yang dari waktu ke waktu 
melalui pengumpulan data yang mendalam serta melibatkan berbagai sumber informasi yang "kaya" dalam suatu konteks. Sistem terikat ini diikat oleh waktu dan tempat, sedangkan kasus dapat dikaji oleh suatu program, peristiwa atau suatu individu (Creswell, 1998: 61). Penelitian studi kasus dapat dibedakan menjadi tiga tipe, yaitu studi kasus eksplanatoris, eksploratoris, dan deskriptif. Dalam penelitian mengenai CSR "program Kampoeng BNI" sebagai program yang mendapatkan penghargaan terbaik, peneliti memilih menggunakan tipe eksploratoris. Studi kasus dengan tipe eksploratoris bertujuan untuk mengeksplorasi informasi secara tuntas terkait implementasi CSR melalui program "kampoeng BNI".

Komunikasi dipandang sebagai saling berbagi pengalaman antar individu. Hubungan baik antar individu mendapatkan kedudukan yang tinggi dalam studi kasus. Studi kasus juga lebih mengarah pada analisis interpretatif terhadap suatu fenomena atau realitas sosial dari sudut pandang orang yang mengalaminya. Dalam penelitian ini, tradisi studi kasus digunakan untuk menganalisis Program Kampoeng BNI dalam upaya mendapatkan penghargaan CSR terbaik se ASEAN berdasarkan sudut pandang pihak-pihak yang terkait dengan proses kegiatan program tersebut.

Creswell menyarankan peneliti dalam penelitian studi kasus untuk mempertimbangkan kasus-kasus yang berpotensi sangat baik dan bermanfaat. Kasus tersebut dapat berjenis tunggal atau kolektif; banyak lokasi atau lokasi tunggal terfokus pada kasusnya itu sendiri atau pada isu yang ingin diteliti (instrinsic atau instrumental) (Creswell, 1998: 62).

Adapun teknik-teknik pengumpulan data dalam penelitian ini adalah wawancara mendalam, observasi, dan studi dokumentasi. Wawancara mendalam adalah teknik mengumpulkan data atau informasi dengan cara bertatap muka langsung dengan informan agar mendapatkan data lengkap dan mendalam. Observasi yang digunakan adalah observation nonpartisipant atau observasi non partisipasi dimana peneliti tidak terlibat dalam terhadap kegiatan atau objek yang diteliti yaitu yang berkaitan dengan program CSR yang dilakukan oleh BNI. Sedangkan untuk studi dokumentasi, Guba dan Lincoln dalam Moleong (2007: 216) menjelaskan bahwa dokumen adalah setiap bahan tertulis ataupun film. Untuk itu, peneliti menggunakan dokumen berupa setiap bahan tertulis untuk mendukung penelitian ini.

Teknik penentuan Key Informan peneliti menggunakan teknik Purposive Sampling. Menurut Ruslan (2003: 156) mendefinisikan Purposive Sampling sebagai "Pemilihan sample berdasarkan karakteristik tertentu yang dianggap mempunyai sangkut pautnya dengan karakteristik populasi yang sudah diketahui sebelumnya".

Dalam hal ini informan kuncinya adalah (1) Divisi CCR (Comunity Corporate Responsibility) PT. BNI (persero) tbk serta dinas terkait yang diajak bekerja sama sehingga terlibat langsung dalam implementasi CSR diberbagai daerah yang menjadi target CSR BNI, (2) Masyarakat yang menerima bantuan CSR berupa pinjaman lunak dari BNI. Masyarakat yang dimaksud adalah masyarakat Muara Angke Jakarta Utara yang menerima bantuan berupa "Kampoeng BNI" Ikan Asin, dan (3) Panitia Pelaksana ABA (ASEAN Bussiness Award) yang memberikan penghargaan kepada BNI dalam meraih CSR terbaik se Asia Tenggara karena Panitia ABA mengetahui faktor-faktor yang mempengaruhi CSR BNI hingga mendapatkan penghargaan.

\section{HASIL DAN PEMBAHASAN}

Hasil wawancara yang dilakukan kepada ketiga pihak yang terlibat dalam perencanaan dan pelaksanaan program "Kampoeng BNI" yakni Pihak BNI, Pihak lain (Dinas PHPT, Bapak Angkat, ABA), dan Mitra Binaan BNI, ditemukan adanya faktor-faktor yang melatarbelakangi dibentuknya Program "Kampoeng BNI", diantaranya: (1) Misi BNI (2) Undang-Undang (3) Corporate Social Responsibility dan (4) Ekonomi

Dari kesimpulan yang telah dipaparkan di atas dapat digambarkan kedalam pola dalam Gambar 1 di halaman selanjutnya.

Berbagai perbedaan jawaban yang disampaikan oleh key informan mengenai Latar Belakang Program "Kampoeng BNI" muncul dikarenakan itu semua muncul dari bagaimana orang tersebut memandangnya. Pandangan tersebut dapat pula dipengaruhi oleh berbagai faktor, seperti pengetahuan, pengalaman, faktor emosional, dan juga latar belakang budaya masing-masing individu. 


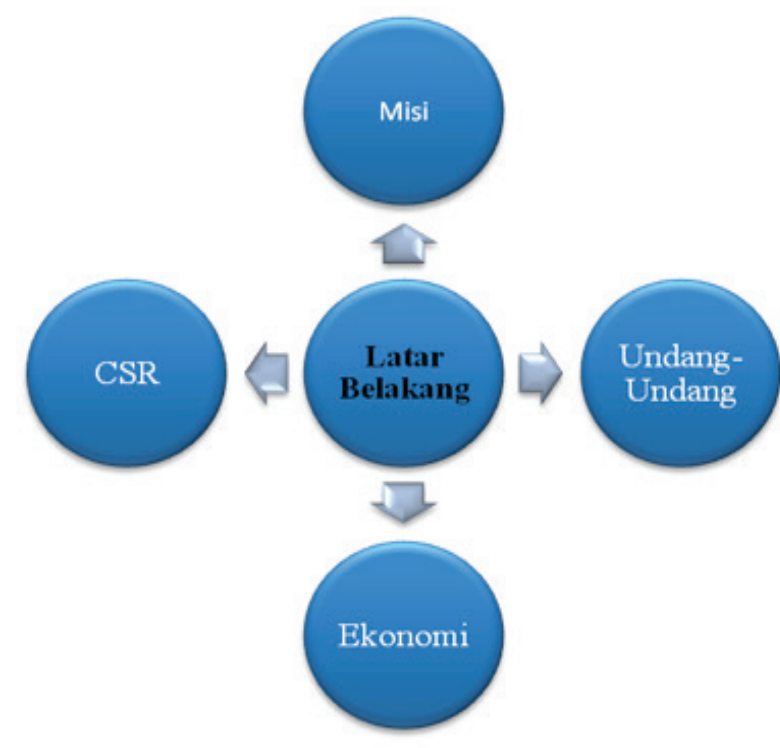

Gambar 1 Latar Belakang dilaksanakannya Program "Kampoeng BNI"

Implementasi Program "Kampoeng BNI" yang dilakukan oleh BNI hingga mendapat penghargaan CSR terbaik se ASEAN oleh ASEAC BAC menurut teori interaksi simbolik yang diungkapkan Mead dimulai dengan pikiran (Mind) bahwa Program "Kampoeng BNI" merupakan sebuah simbol kemudian di proses didalam mind pihak BNI yang mendorong BNI sebagai sebuah perusahaan atau self melakukan sebuah kegiatan interaksi dalam sebuah program "Kampoeng BNI" untuk masyarakat (society) serta dianggap berhasil oleh masyarakat hingga mendapatkan penghargaan dari pihak lain.

BNI menganggap bahwa menjalin hubungan yang harmonis merupakan sesuatu yang penting untuk dilakukan. BNI untuk menjadi bank yang unggul tidak hanya merupakan sebuah ide semata, melainkan telah menanamkan strategi intinya melalui penjabaran misi-misinya tersebut. Menurut Morissan yang mengatakan bahwa "Suatu pernyataan misi perusahaan biasanya memiliki karakteristik untuk menunjukan kepedulian perusahaan atau organisasi kepada masyarakat (2008: 155)".

Konsep CSR saat ini sudah menjadi suatu arus pemikiran utama. Buktinya, di Indonesia sendiri CSR telah diperkuat dengan adanya regulasi yang dibuat oleh pemerintah terkait kewajiban BUMN dalam melakukan CSR. Adapun Regulasi yang mengatur mengenai
CSR di Indonesia, salah satunya adalah Undang - Undang No. 40 Tahun 2007 mengenai Perseroan Terbatas (PT). CSR wajib dijalankan oleh perusahaan tidak hanya karena berlandaskan atas hukum yang dibuat pemerintah untuk menghindari sanksi yang diberikan, melainkan atas kesadaran yang muncul guna merealisasikan etika bisnis untuk kelangsungan perusahaan. Kegiatan CSR yang diterapkan dalam aktivitas perusahaan menimbulkan situasi saling percaya antara perusahaan dan stakeholders, yang memungkinkan perusahaan meningkatkan keuntungan jangka panjang (Susanto, 2009: 35).

CSR juga menekankan kepada aspek berkelanjutan dalam hal pembangunan atau pengembangan masyarakat. Berdasarkan konsep Triple Bottom line menurut John Elkington (dalam Rachman dkk, 2011: 12) mengenai pengembangan masyarakat mencakup tiga hal kebijakan, yaitu pembangunan ekonomi, sosial dan lingkungan yang digambarkan oleh John Elkington dalam bagan triple bottom line sebagai pertemuan dari tiga pilar pembangunan yaitu "Orang, planet, dan keuntungan" yang merupakan tujuan pembangunan. Komitmen perusahaan untuk berkontribusi dalam pembangunan bangsa dengan memperhatikan aspek finansial atau ekonomi, sosial, dan lingkungan (triple bottom line) itulah yang menjadi isu utama dari konsep Corporate Social Responsibility (CSR) atau tanggung jawab sosial perusahaan. Maka dari itu sebuah perusahaan harus memperhatikan stakeholders yang tentunya akan sangat berpengaruh dalam keberlangsungan perusahaan itu sendiri.

Teori Stakeholders dalam konteks ini sangat relevan untuk mengkaji fokus penelitian yang dilakukan peneliti. Teori Stakeholders menjelaskan bahwa CSR yang dilakukan oleh perusahaan sebagai salah satu cara untuk berkomunikasi dengan stakeholders. Salah satu prinsip dasar dari teori stakeholders adalah "Organisasi harus memenuhi kebutuhan secara luas keinginan stakeholder yang pencapaiannya melebihi stockholders (pemilik perusahaan) (Ardianto, 2011: 125).

Konsep CSR telah lama diperbincangkan di Indonesia, dan telah menjadi isu utama dalam etika bisnis perusahaan. Tujuan perusahaan melakukan CSR salah satunya adalah untuk memperdayakan ekonomi masyarakat, 
untuk itulah ekonomi menjadi salah satu latar belakang Program "Kampoeng BNI" yang dilakukan oleh BNI.

Banyak cara bagi perusahaan yang ingin ikut berperan dalam meningkatkan ekonomi guna memecahkan permasalahan kemiskinan di Indonesia. Salah satunya dengan mencari calon mitra binaan yang mempunyai potensi dalam mengembangkan usahanya. Melalui hal itu, perusahaan bisa dikatakan melakukan CSR berdasarkan motif ekonomi. Iwan Sukoco (2012) pada salah satu penelitiannya tentang CSR Program Kemitraan menyatakan bahwa pada dasarnya setiap perusahaan dalam melakukan aktivitas CSR dilatar belakangi karena kesadaran bisnis. Artinya CSR bisa menjadi investasi sosial dan investasi bisnis. Investasi sosial yakni perusahaan mendapat kepercayaan dari para stakeholdernya sedangkan investasi bisnis jika usaha mitra binaan BNI dapat berkembang, maka mereka akan semakin loyal dalam menggunakan jasa dan layanan dari BNI.

Berdasarkan hasil wawancara yang dilakukan kepada key informan dapat diketahui bahwa BNI mempunyai cara tersendiri dalam mengimplemen-tasikan Program Kemitraannya. Strategi serta taktik yang dijalankan oleh BNI dalam implementasi Program kampoeng BNI eksekusi awalnya dilakukan oleh SKC atau Kantor Cabang, langkah-langkahnya adalah (1) Mendefinisikan masalah (2) Membuat rencana dan program (3) Aksi dan Komunikasi dan (4) Evaluasi.

Pada saat membuat rencana dan program, Divisi CCR dilibatkan oleh SKC Melawai untuk membantu dalam menentukan (1) Penyaluran Dana (2) Pembentukan Program yang meliputi pembentukan kerjasama, pembentukan klaster, dan pelatihan serta perbaikan infrastruktur (4) Pengukuhan atau Peresmian dari pembuatan gapura, penandatanganan, dan hiburan.

Dari kesimpulan yang telah dipaparkan diatas dapat digambarkan kedalam pola sebagai berikut:

SKC awal mulanya melakukan survey ke lokasi yang menjadi sasaran Program "Kampoeng BNI". Hasil survei tersebut kemudian dirumuskan kedalam sebuah proposal. Proposal tersebut diajukan oleh SKC atau Kantor Cabang yang ingin membuat sebuah program diwilayahnya kepada Divisi CCR untuk memutuskan apakah rencananya tersebut disetujui atau tidak. Proposal tersebut diantaranya berkenaan pula dengan anggaran program "Kampoeng BNI" didaerah setempat.

Kegiatan perusahaan dalam sebuah program tidak terlepas dari anggaran. pada fase ini perusahaan perlu mengkajinya lebih dalam, sebab dalam fase aksi dan komunikasi, hanyalah merupakan langkah kecil dari langkah lain yang jauh lebih penting, itu artinya apabila proses pada langkah yang mendahuluinya tidak benar, maka langkah ketiga hanyalah mengha-

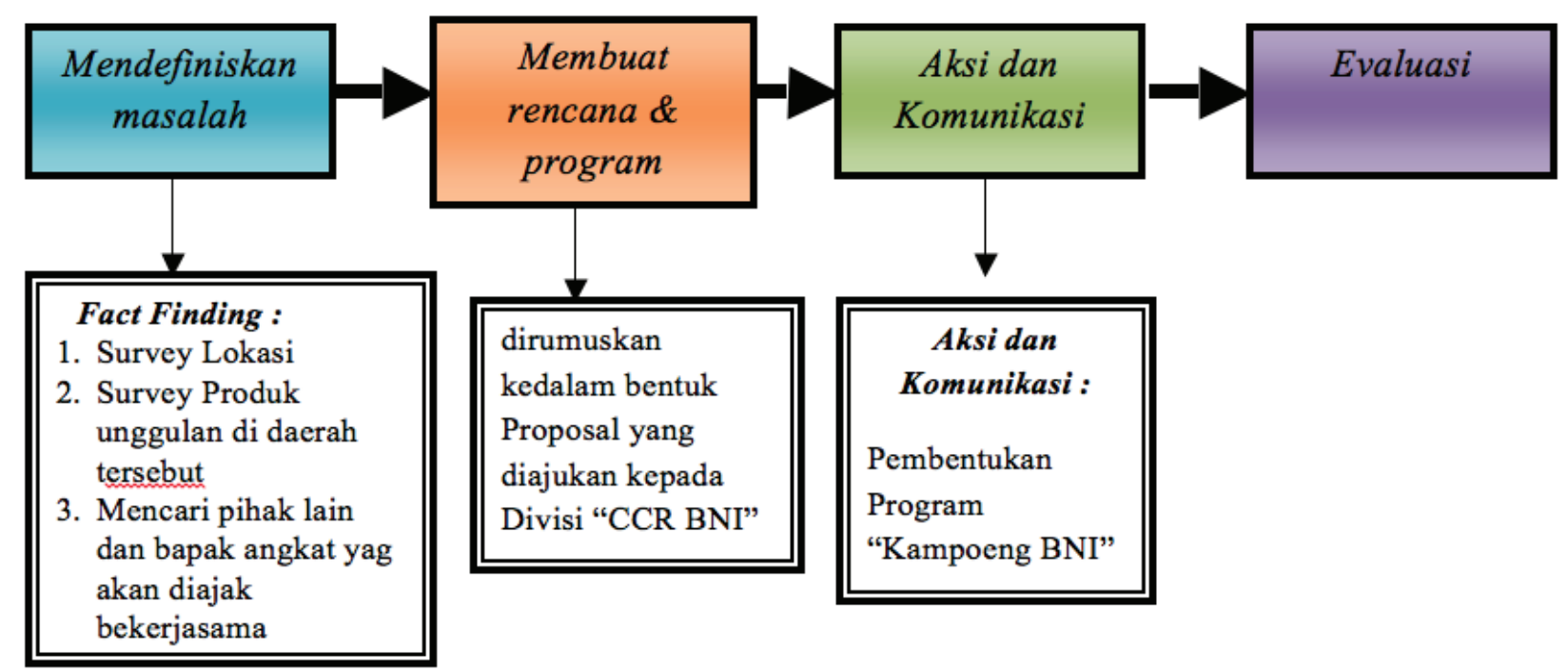




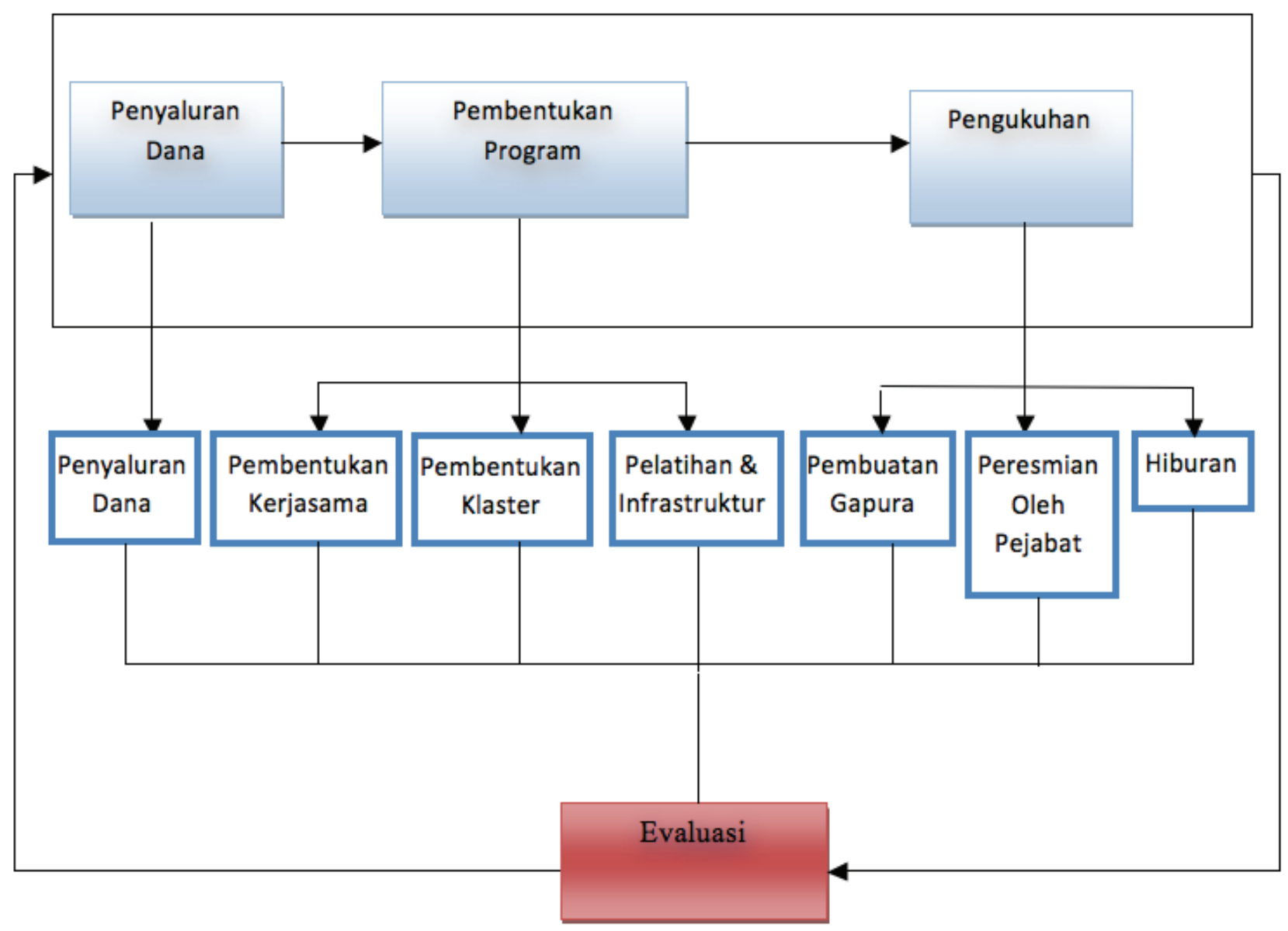

Gambar 3 Implementasi program "Kampoeng BNI" oleh divisi CCR dan SKC Melawai

biskan anggaran perusahaan secara cuma-cuma (Kasali, 2008: 97). Dana atau anggaran yang disiapkan oleh perusahaan khsususnya BUMN dalam pelaksanaan program CSR terakumulasi dari laba perusahaan setelah pajak sebesar 4\% per tahun. Dana tersebut dibagi untuk Program Kemitraan dan Bina Lingkungan. BNI sendiri membaginya, $1 \%$ untuk program kemitraan dan 3\% untuk Bina Lingkungan.

Pendampingan pada saat implementasi program CSR dilakukan dengan upaya memperkuat kapasitas lembaga kolaborasi. Perusahaan dalam mengeksekusi program-program CSR tanpa melibatkan pihak atau dinas terkait untuk diajak kerjasama merupakan sesuatu hal yang sulit. Karena tidak menutup kemungkinan akan terjadinya resistensi masyarakat setempat. Pihak lain dan Dinas setempat yang dilibatkan dalam pelaksanaan CSR tidak hanya berfungsi sebagai pendamping, melainkan juga sebagai fasilitator, pelatih ataupun mediator.

Proses pembentukan klaster sesuai dengan proses pengenalan situasi. Dalam pengenalan situasi disini berarti mengajukan beberapa per- tanyaan mengenai siapa saja pelaku industri didaerah yang menjadi target Program "Kampoeng BNI" berapa banyak dan bagaimana kondisi usaha yang mereka jalani. Tahap pembentukan klaster dibantu dengan Focus Group Discussion (FGD). Tujuannya untuk mendefinisikan khalayak utama yang akan menjadi sasaran utama dalam program ini.

Pembentukan program "Kampoeng BNI" selanjutnya adalah pelatihan dan perbaikan infrastruktur (jika memang diperlukan). Pembentukan kerjasama yang dilakukan oleh BNI kepada dinas PHPT salah satu tujuannya adalah untuk memberikan pelatihan kepada calon mitra binaan BNI. Pembuatan gapura yang dilakukan oleh BNI adalah untuk memberikan tanda kepada BUMN lain bahwa telah ada sebuah program dari BNI berupa program "Kampoeng BNI" di daerah Muara Angke. Lebih lanjut, tujuannya menunjukan sebagian masyarakat di Muara Angke telah menjadi mitra bina BNI. Sebenarnya mengenai pembuatan gapura jika dikaitkan dengan konsep-konsep CSR BNI sedang membangun corporate image, karena corporate im- 
age terbentuk dari asosiasi antara perusahaan dengan sekumpulan atribut positif maupun negatif. Menurut Susanto, corporate image berada dalam benak para stakeholderss-nya. Image dibentuk ketika manusia akan memproses stimulus yang ditangkap oleh indera (apersepsi) dan kemudian menafsirkannya (persepsi) dengan memberi arti melalui asosiasi berdasarkan pengetahuan yang dimiliki sebelumnya (Susanto, 2009: 20)

Berdasarkan hasil wawancara kepada event ABA ditambah dengan pendapat pihak yang terlibat dalam pelaksanaan Program "Kampoeng BNI", maka didapatkan bahwa faktor-faktor penentu kemenangan BNI ditentukan berdasarkan faktor-faktor seperti kerangka kerja untuk CSR, kesesuaian dengan standar international, komitmen pelaksanaan program CSR, dan implementasi program CSR.

Berdasarkan dari kesimpulan-kesimpulan yang didapat dari hasil wawancara kepada key informan, maka dapat digambarkan dengan pola seperti yang ditunjukkan pada gambar 4 .
Kesuksesan mengimplementasikan sebuah program dapat terukur dari tercapainya tujuan perusahaan. Jika tujuan program dapat tercapai, bisa dikatakan program tersebut telah sukses, terlebih lagi program yang diimplementasikannya mendapatkan penghargaan di tingkat ASEAN. Program "Kampoeng BNI" yang telah dimulainya sejak tahun 2007 pada akhirnya membuahkan hasil. Itu terbukti dari penghargaan yang diberikan oleh ASEAN BAC (Bussiness Advisory Council) selaku penyelenggara event ABA (ASEAN Bussiness Award) kepada BNI ditahun 2012. Secara pengamatan, tentunya CSR yang dilakukan oleh BNI telah memenuhi kriteria sebagai pemenang yang ditentukan oleh ASEAN BAC selaku penyelenggara event tersebut.

Sejauh ini belum ditemukan bagaimana standar atau praktik-praktik tertentu yang dianggap terbaik dalam mengimplementasikan aktivitas CSR. setidaknya menurut Susanto "Kerangka kerja (framework) yang luas dalam pengimplementasian CSR masih dapat dirumuskan yang

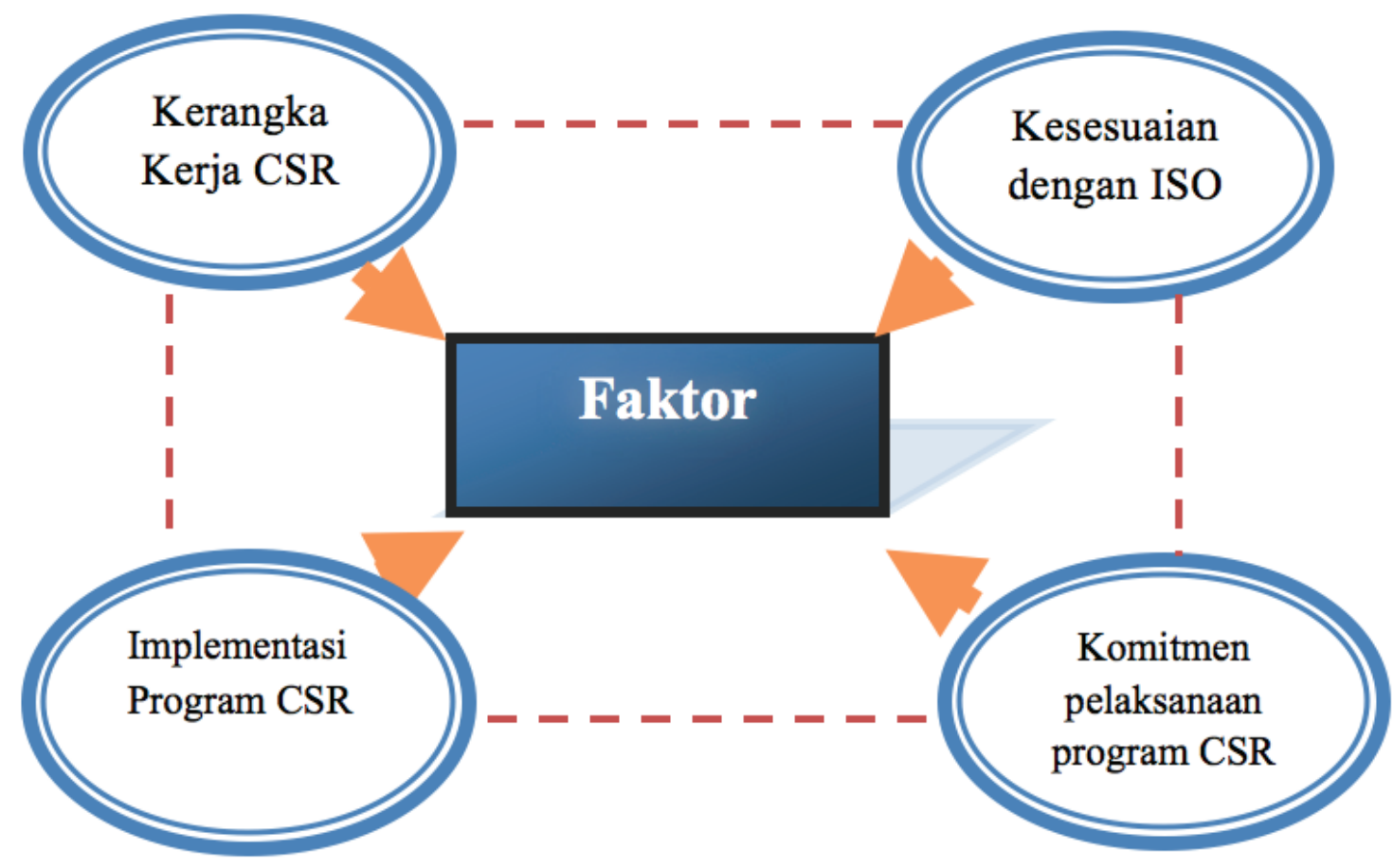

Gambar 4 Faktor-Faktor penentu Kemenangan BNI untuk Kategori CSR terbaik se ASEAN oleh ASEAN-BAC melalui Program "Kampoeng BNI" 
didasarkan pada pengalaman dan juga pengetahuan (Susanto, 2009: 50). Langkah-langkah perencanaan dalam membuat kerangka CSR akan mempermudah untuk memasuki tahap berikutnya, sehingga dalam tahap ini perusahaan dituntut untuk lebih teliti dalam menganalisisnya.

BNI dalam membuat kerangka CSR membutuhkan waktu yang cukup lama. Survey yang dilakukan oleh Tim SKC Melawai untuk mengimplementasikan Program "Kampoeng BNI" di Muara Angke tidak hanya dilakukan sebagai sebuah persyaratan dalam pembuatan proposal, pertimbangan segala macam kemungkinan yang akan menghambat program-pun perlu diperhatikan.

Kerangka konsep etika bisnis terdapat pengertian tentang "Etika perusahaan, etika kerja, dan etika perorangan yang menyangkut hubungan-hubungan sosial antara perusahaan, karyawan dan lingkungan" (Susanto, 2009: 35). Implementasi Program "Kampoeng BNI" yang tersebar di seluruh Indonesia bisa dikatakan bahwa BNI telah melaksanakan etika bisnis dengan konsep etika perusahaan, sehingga bisa disebut BNI telah melakukan GCG sebagaimana mestinya. Perkembangan CSR dari masa ke masa ditandai dengan adanya inisiatif standar secara internasional dalam bentuk ISO diantaranya ISO 26000. ISO 26000 menyatakan bahwa Corporate Social Responsibility adalah "Bentuk kepedulian sosial perusahaan yang saat ini menjadi aspek penting dalam rangka peningkatan kinerja perusahan" (Rachman, 2011 : 37).

Kontribusi pada komunitas dan masyarakat yang merupakan salah satu isu dari ISO 26000 rupanya BNI telah menerapkan isu kontribusi pada komunitas dan masyarakat melalui program "Kampoeng BNI". BNI mencoba memberikan manfaat kepada komunitas serta masyarakat luas mengenai keberadaan perusahaannya yang tersebar di Indonesia melalui program "Kampoeng BNI". Program yang berbasis pada pengembangan ekonomi masyarakat tersebut diharapkan dapat membantu dalam memberdayakan ekonomi dan sosial. Dari segi ekonomi, diharapkan masyarakat dapat menjadi pengusaha yang tangguh dan mandiri sedangkan dari segi sosial diharapkan dapat membantu dalam peningkatan kesejahteraan hidup.

Komitmen CSR adalah "Instrumen-instrumen yang dibangun oleh sebuah perusahaan yang mengindikasikan apa yang dilakukan da- lam rangka memberi perhatian terhadap pengaruh sosial dan lingkungannya" (Susanto, 2009: 53). BNI jika dikaji mengenai komitmen CSR terlihat dari eksistensi program "Kampoeng BNI" yang tersebar di Seluruh Indonesia. Hingga saat ini, BNI berkomitmen membantu masyarakat Indonesia dari segi pemberdayaan ekonomi. Programnya tersebut tidak hanya dirasakan oleh masyarakat yang berdomisili di Pulau Jawa, tetapi telah merambah ke luar pulau jawa seperti Sumatera dan Sulawesi.

Perusahaan dalam mengkomunikasikan dan mengimplementasikan komitmen CSR dapat dilakukan dengan cara verifikasi dan laporan mengenai kemajuan. Verifikasi dan Pelaporan adalah "alat yang penting untuk mengukur apakah kinerja yang dihasilkan sudah sesuai dengan yang diharapkan sehingga memberi pihak-pihak yang berkepentingan kesempatan untuk menilaht seberapa baik perusahaan memenuhi komitmennya serta pengaruh yang ditimbulkan" (Susanto, 2009: 62).

\section{SIMPULAN}

Simpulan dari penelitian ini antara lain, latar belakang Program "Kampoeng BNI" dibelatarbelakangi beberapa faktor yaitu Kesesuaian dengan misi BNI, memenuhi kewajiban perusahaan kepada Undang-Undang, sebagai Corporate Social Responsibility (CSR) perusahaan, dan membantu ekonomi masyarakat Indonesia.

Implementasi Program "Kampoeng BNI" dilakukan dengan dua 2 tahap. Tahap pertama dilakukan oleh SKC Melawai dengan cara mengidentifikasi masalah, membuat rencana dan program, Aksi dan Komunikasi, dan evaluasi. Sedangkan tahap kedua dilakukan oleh Divisi CCR yang bersinergi dengan SKC Melawai dengan melakukan penyaluran dana, pembentukan program dan pengukuhan.

Terdapat empat faktor penentu kemenangan BNI untuk kategori CSR terbaik se-ASEAN oleh ASEAN-BAC melalui program "Kampoeng BNI, diantaranya Kerangka CSR, Ikuti panduan dan standar Internasional tentang CSR, Komunikasi komitmen perusahaan untuk CSR, Implementasi dan pengukuran Program CSR.

Saran yang peneliti ajukan berdasarkan hasil penelitian ini yaitu pertama, perlu kiranya BNI memberikan pelatihan kepada calon mitra binaan dengan waktu yang lebih intens selama 
program berlangsung, tidak hanya 1 hari saja. Hal tersebut dimaksudkan untuk meminimalisir faktor-faktor yang menghambat keberhasilan produksi.

Kedua, selalu membina hubungan baik dengan mitra bina dan bapak angkat baik selama proses Program "Kampoeng BNI" berlangsung maupun setelah Program tersebut selesai.

Ketiga, BNI perlu menggalakan lagi Program "Kampoeng BNI" didaerah lain. Terutama diluar pulau jawa yang masih sedikit merasakan Program Kemitraan BNI.

Terakhir, BNI harus menemukan ide-ide baru terkait Program Kemitraan, sehingga dapat dijadikan sebagai patokan keberhasilan Program Kemitraan oleh perusahaan lain.

\section{DAFTAR PUSTAKA}

Ardianto, E. \& Bambang Q-A. (2011). Filsafat Ilmu Komunikasi. Bandung: Simbiosa Rekatama Media.

ASEAN-BAC. (2012). Diakses 1 Februari 2013 dari www.asean-bac.org.

BNI. (2012). Sejarah BNI. Diakses 1 Februari 2013 dari http://www.bni.co.id/id-id/tentangkami/ sejarah .aspx. . (2012). Visi misi. Diakses 1 Februari 2013 dari http://www.bni.co.id/id-id/tentangkami/ visimisi .aspx.

. (2012). Kampoeng BNI. Diakses 18 Februari 2012 dari http://www.bni.co.id/TentangKami /CorporateSocialResponsibility/ ProgramKemitraan/KampoengBNI.aspx

Creswell, W. J. (1998). Qualitative inquiry and research design choosing among five tradi- tion. Sage Publications

Hidayat, D. N.(1999). Paradigma dan perkembangan penelitian komunikasi vol III. Jakarta: IKSI dan ROSDA.

Kartini, D. (2009). Corporate social reponsibility, transformasi konsep dan aplikasinya di Indonesia, Jakarta: Grafitipers.

Kasali, R. (2008). Manajemen public relations. Jakarta: Pustaka Utama Grafiti

Morissan, M. A. (2008). Manajemen public relations. Jakarta: Prenada Media Group

Moleong, J. L. (2007). Metodologi penelitian kualitatif. Bandung: Remaja Rosdakarya

Rachman, E. \& Wicaksono. (2011). Paduan lengkap perencanaan CSR. Jakarta: Penebar Swadaya

Ruslan, R. (2003). Metode Penelitian PR dan komunikasi. Jakarta: Raja Grafindo Persada

Susanto, A.B. (2009). Reputation-driven, corporate social responsibility, pendekatan strategic management dalam CSR. Jakarta : Esensi

(2010). Kampoeng BNI Tenun Sumatera Selatan: kemitraan membangun negeri melalui industri kreatif. Jakarta: Bank Negara Indonesia

Sukoco, I. (2012). Disertasi. studi kasus pada program kemitraan sebagai salah satu pilar CSR PT Telekomunikasi Indonesia. Bandung: Universitas Padjadjaran.

Undang-Undang No. 40 Tahun 2007

Kompas. (2012). Ciptakan lapangan kerja, BNI terbaik se-Asia Tenggara. Diakses dari http://bisniskeuangan.kompas.com/ $\mathrm{read} / 2012 / 11 / 18 / 10011399 /$ Ciptakan.Lapangan.Kerja.BNI.Terbaik.se-Asia.Tenggara. 